Supplement of The Cryosphere, 11, 1213-1233, 2017

http://www.the-cryosphere.net/11/1213/2017/

doi:10.5194/tc-11-1213-2017-supplement

(C) Author(s) 2017. CC Attribution 3.0 License.

(c) (i)

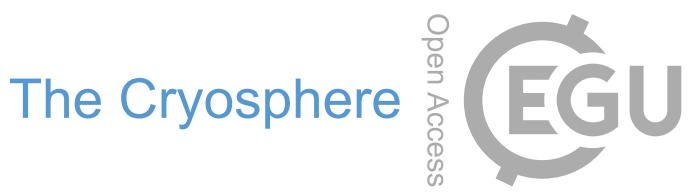

Supplement of

\title{
Properties of black carbon and other insoluble light-absorbing particles in seasonal snow of northwestern China
}

W. Pu et al.

Correspondence to: Xin Wang (wxin@lzu.edu.cn)

The copyright of individual parts of the supplement might differ from the CC-BY 3.0 licence. 

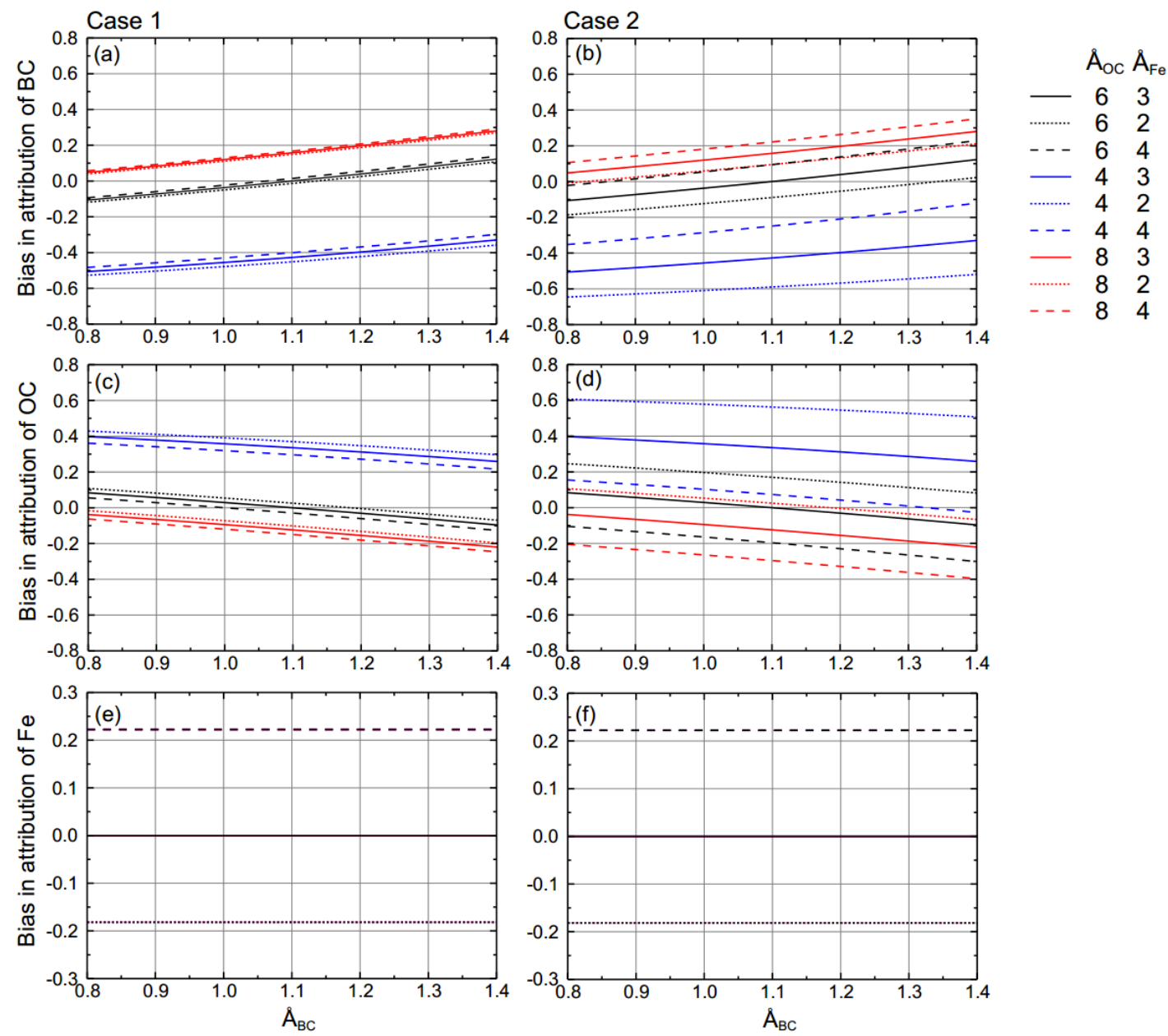

Fig. S1. Uncertainty in attributed absorption of $\mathrm{BC}, \mathrm{OC}$ and $\mathrm{Fe}$ at $450 \mathrm{~nm}$ associated with the changes of Absorption Angstrom Exponent (AAE). Case $1 \& 2$ represent two typical conditions that the fractional absorption of $\mathrm{Fe}$ are $4 \%$ and $23 \%$ in seasonal snow during this field campaign, respectively. 